OPEN ACCESS

Edited by:

Judit Keller,

Centre for Economic and Regional

Studies, Hungary

Reviewed by:

Albin Algotson,

Linköping University, Sweden

Arjan Schakel,

University of Bergen, Norway

${ }^{*}$ Correspondence:

Ilona Pálné Kovács

palne.kovacs.ilona@krtk.hu

Specialty section:

This article was submitted to

Peace and Democracy,

a section of the journal

Frontiers in Political Science

Received: 12 April 2021

Accepted: 30 August 2021 Published: 13 September 2021

Citation:

Pálné Kovács I (2021) Politics Without Meso-Level? No Politics at the Meso?

Front. Polit. Sci. 3:694260.

doi: 10.3389/fpos.2021.694260

\section{Politics Without Meso-Level? No Politics at the Meso?}

\author{
Ilona Pálné Kovács ${ }^{1,2 *}$ \\ ${ }^{1}$ Department of Political Science, University of Pécs, Pécs, Hungary, ${ }^{2}$ Institute of Regional Studies, Centre for Economic and \\ Regional Studies, Budapest, Hungary
}

The paper examines the role of meso-level governance in the Hungarian political system focusing on the county self-governments. The objective of the author is to introduce the consequences of the lack of meso-level politics for the backslide of the democratic system. The paper focusing on Hungarian counties seeks to explore the three-decade-long process leading to the progressive elimination of these bodies from the public power arena. The Hungarian case demonstrates how the overall administrative and political centralisation process has contributed to the hollowing-out of meso-level political actors. The Hungarian case study underlines the complex interrelations between the macro-political system, and the territorial political governmental arenas from the aspect of the centre and periphery power relations. Many European regional governments are not only platforms for territorial interest representation but also a counterweight to the central level contributing to the quality and stability of democratic governance. The study reviewing the situation of Hungarian counties draws on the author's previous empirical research experiences and is a part of the ongoing research on governance issues of peripheral areas ${ }^{1}$. The results of the analyses discuss the implications of the hollowing-out of county governments on the electoral and party system, the modification of the institutional channels of interest representation. The Hungarian example appears to corroborate the analogy with the theory of second order elections. The theory of second order elections recognized the impact on the turnout and electoral preferences based on the changing role of different governance levels, by the same token, it seems that the weakening power position of the meso contributes to the decline of political competition and publicity by minimizing the interest of the public in general. The objective of the present study is to enrich the assessment of the relationship between territorial governance and democracy with some analytical options by demonstrating the implications of the "second order nature" of the meso.

Keywords: meso-level governance, Hungarian counties, centralization, elections, parties

\section{INTRODUCTION}

Territorial (meso, regional) governance is a widely explored issue in regional studies, public administration sciences and public policy studies. There has been a growing scholarly appreciation of the pivotal role of second (or third)-level governance (Jeffery, 1997), but generally overlooked by mainstream political scientific research. The evolution of governance

${ }^{1}$ KÖFOP-2.1.2.-VEKOP-15-2016-0001, and NKFIH, No:132294 
systems over the last decades has provided a significant impetus to analysing the emerging trends of territorial governance not only in federations and in countries with strong regional autonomy movements. The role of regions is dominantly (but not exclusively) shaped by vertical power relations. Within the multilevel system of governance, meso-level units are responsible not only for the management of public services and other economic development functions, but these are vital political actors with representative and integrative/mediatory/ complementary missions. It is assumed that their power position crucially impacts the performance and legitimacy of both the local and central government system and the quality of democracy as a whole.

However, apart from regional elections and regional ethnic, national movements the subnational levels have been largely ignored by political science. Local and territorial governance structures are regarded as second order platforms of politics subordinated to the national level. The theory of second order elections postulates that local, territorial levels are actors of minor or no relevance and a limited influence on power relations. This theory has recently been challenged by a substantial body of political science literature. Refuting the claims of the theory grounding the analysis of European parliamentary elections, they underline the often non-negligible political significance of regional elections (Schakel and Jeffery, 2012). Extensive comparative studies on regional elections launched and published by Regional and Federal Studies (Schakel and Romanova, 2018; Schakel and Romanova, 2020) allow for a deeper insight into meso-level election systems and results and their complex implications on national and multilevel political and governance systems. Other studies have pointed out that the legitimacy of subnational levels is corroborated by external factors beyond elections (Haus, 2014).

Despite contrary claims gaining growing recognition over the past few years, the picture at meso-level is still very diverse (Gendzwill and Steyvers, 2021). Compared to the local/ municipal level, meso-level governance is more heterogeneous in terms of scale, legal status, competences and political aspects as well. The political significance of the meso- or second-third level of governance as the key condition of modern decentralised democracies is not always evident. In some countries, the pivotal macro political role of regions (alternatively, counties, districts, provinces, etc.) stems from their ethnic composition or other (political, historical, cultural, economic) factors highlighted by the wave of "new regionalism" (Keating, 2004). In others, meso-level government units are practically invisible due to their apolitical administrative (deconcentrated, not elected) status and also directly elected self-government bodies with a limited role and scope of action can exist in a political vacuum, loosely connected to higher and lower tiers of government.

The present study discusses the implications of the absence of the meso extending beyond electoral results. While the case of Hungary is far from unique, the changes of the last 30 years have been extraordinarily turbulent, which enabled us to examine the extent to which the concentration of power contributed to the liquidation of counties as autonomous political stakeholders. The empirical researches of the author do not allow for a comprehensive treatment of each question, which narrows the scope of the study only to some aspects: 1) how the general changes of political governance have led to the hollowing out of the meso, 2) how the changes in the regulatory model of elections have modified the presence of parties and civil organisations at meso level, 3) how the drastic downsizing of the functions of counties has modified electoral turnout and the interest of voters, 4) how Hungarian county governments are functioning without power.

The structure of the paper is as follows: Section Meso-Tier/ Region as a Platform of Multi-Level Politics in Europe demonstrates the tendency of the reinforcement of the temporally and spatially heterogenous power position and model of the meso tier in Europe. Sections The History of Hungarian Counties, Politics Between the Top and the Bottom Focusing on the Elections and Governing Without Power? Some Empirical Evidence About the Functioning of County Assemblies provides a lengthier and more in-depth discussion of the history of Hungarian meso-level governance on the basis of empirical researches. The closing section presents a summary of the results with the ambition to explore some questions for further studies.

\section{MESO-TIER/REGION AS A PLATFORM OF MULTI-LEVEL POLITICS IN EUROPE}

\section{Trends}

This section is about the rising power of regions in Europe within the frames of the European integration. Despite the evolving and asymmetric nature of regionalisation, it has generally contributed to the better quality of governance and democratic systems providing an essential arena for competition and cooperation.

Popular but often schematic views in the eighties and nineties promoted decentralisation as a political value to be embraced globally (Shabbir and Rondinelli, 2007). Decentralisation emerged as a general criterion of democracy without any objective assessment of its pertinence corroborated by sufficient and reliable evidence and methodology (Litvack et al., 1998). In addition to participation and transparency as democratic requirements, and the quality and efficiency of governance (Kaufmann et al., 2003), the territorial division of governance has received great emphasis in international comparative studies. The local autonomy index (Ladner et al., 2019), and later on, the regional authority index (RAI) (Hooghe et al., 2010; Hooghe et al., 2016) represented significant methodological advancements in the objective evaluation of territorial governance. These efforts underline the special significance of territorial/meso governance within the system of multi-level governance. However, the situation and model of the meso-level have been influenced by a complex set of factors in various countries of Europe.

Informed by the concept of Europeanisation, there has been a general effort to remodel national governance systems according to neoliberal principles and models, promoting, among others, decentralisation and regionalisation (Bache et al., 2011). However, while the European standards of "good governance" were predominantly shaped by the more advanced old member 
states, the newly emerging Eastern democracies struggled to embrace Western regional pattern(s) (Junjan, 2012). Rescaling, i.e. the construction of bigger and more competitive regions was at the core of European governance and development strategies, but the concrete political, social conditions were not clarified. Downplaying the role of the unique cultural context has contributed to the failure of multiple territorial reforms in Eastern-Europe (Pálné Kovács, 2016). Regionalisation has been largely unsuccessful in mitigating regional development disparities (Loewen, 2018). Given the failure of regionalisation in the newly integrated post-Soviet democracies and the transitory regionalisation "climax" affecting Western Europe, Michael Keating, the "pope" of "new regionalism" acknowledged that regionalism was a process rarely conducive to a new power structure overnight and regions could formally exist without regionalism (Keating, 2014).

Relentless reforms, rescaling and organizational changes testify of an extraordinarily turbulent period in territorial governance (Loughlin et al., 2011; Bertrana and Heinelt, 2013; Kuhlmann and Wollmann, 2014; Heinelt et al., 2016), whose implications on the system of governance as a whole are still largely unknown. As shown by the new results of RAI (Hooghe et al., 2016), authoritarian regimes with a general disdain towards decentralisation and local governments are less keen on pursuing regional reforms. The results underline the critical importance of regional identity and strong economic embeddedness in the multi-level governance system. A similarly understudied issue is how the expansion of urban spaces contributes to reshaping the territorial structure of governance (Brenner, 2004). New relations and conflicts are generated by the activity and significance of mesolevels and "giant" metropolises that go beyond national borders (Faguet et al., 2015: 152). A growing corpus of studies point to the global collaboration of territorial, especially metropolitan and regional governments (Curtis, 2016; Vallier et al., 2018). They advance the claim that the meso-level can only be understood in its relation to other governance levels and that reforms are not reducible to the transformation of geographical scales. Reform processes have produced a very contradictory and complex landscape of territorial governance.

The economic crisis of 2008 was a main trigger of centralization reflexes (Göymen and Sazak, 2014), applied as a transitory strategy in several countries (or rather a temporary tool of crisis management). At the same time, structural reforms at local and meso-levels, e.g. municipal integrations and regionalisation have been pursued with an ambition to further advancing decentralisation (Baldersheim and Rose, 2010; Halásková and Halásková, 2015; Bucek and Plesivcak, 2017).

A Europe-wide shift in the role of regionalism is manifest, among others, in a political sense (Scully and Wyn-Jones, 2010). Regionalism is no longer regarded as a miracle recipe; it is time to investigate its processes and consequences in Europe without illusions in order to be able to fix visions of the future. Over the last decade, fashionable buzzwords such as regional competitiveness, new regionalism and regionalised development policy, subsidiarity and multi-level governance have lost much of their appeal. In the meantime, cohesion (policy) reports of the EU continue to emphasise that regions and regional governance matter (Rodríguez-Pose and Ezcurra, 2010; Charron et al., 2013; Charron, 2016; Rodríguez-Pose and Courty, 2018), in stark contrast with the experience and practice of many countries. The shifting balance of power among various governance levels is also manifest in the management of cohesion funds (Piattoni and Polverari, 2016), highlighting the tension between the EU's enduring principles and centralised implementation in the member states (Bachtler et al., 2017; Loewen, 2018).

While decentralisation and regionalisation are dominant but not the exclusive trend, it is safe to conclude that territorial governance still matters, regions have the potential to become the key actors of economic and social development, however, their nature could be influenced by political (domestic, sometimes global/geopolitical) considerations (Heinelt et al., 2016). The following subsection focuses on aspects whose interpretation in a political science approach is deemed necessary in the case of the meso-tier.

\section{Approaches to Meso-level Politics and Policy}

A number of significant scientific contributions have emerged in the field of local politics with a dominant focus on localities as independent platforms for political games facilitated by their larger room for manoeuvre. For instance, the so-called local community studies (Dahl, 1961; Coleman, 1974) stressing the role of local governance as a relatively independent, separate branch of public power has gained numerous followers mostly in the United States and in other Anglo-Saxon countries. By contrast, in continental Europe, the significance of the macropolitical context is highlighted in the study of localities that confer local governance a pragmatic, executive role, undermining their macro political power relations (Haasis, 1978; Galaskiewicz and Krohn, 1984).

In contrast to research on local politics, outside the realm of elections, the role of the meso-level as a political arena is seldom discussed in the literature (notable exceptions are e.g. Baldersheim and Rose, 2010; Bertrana and Heinelt, 2013; Heinelt et al., 2016). Regions are rather regarded as actors of secondary importance subordinated to national politics and far from the voters. The logic of RAI focuses on the role of the meso level in the system of the distribution of power. The experts have developed metrics to measure, beyond the "self-rule", the "shared rule" domain of authority also referring to the role of regional authorities in nation-wide decision-making. The secondary or dependent role of the territorial/meso level as a passive intermediary between local and central governments is, however, increasingly called into question. Undoubtedly, meso-level governments could aspire toward "shared power" since these are theoretically placed "inconveniently" close to the centre even in non-federative, unitary systems. The meso level as a political sector charged with the generation or resolution of political conflicts and interest representation provides a rich source of information on the political system and processes of a given country when examined in a centre-periphery or vertical 
dimension (Ladner et al., 2019). Electoral studies focusing on regions as domestic actors highlight their increasingly prominent transmitting role in the vertical and horizontal system of governance. Notwithstanding the powerful trends of nationalisation and polarisation, meso-level authorities are contributing to the stability of democracy through their complementary role (Schakel and Romanova, 2020).

Besides the relations underpinning the vertical system of the division of power, more emphasis should be given to the factors driving the emergence, strengthening or weakening of regions. Regions can become particularly salient political stakeholders in the case of ethnic or minority-based polarisation. Regional minority movements have reinforced the role of the meso in countries where national minorities could penetrate the macro-political sphere and become the hotspot of the political arena, menacing with potential secession or as opponents to growing centralization (Dardanelli et al., 2018). The imperative of "regionalism" was not confined to nationally or ethnically regionalised countries alone. Other driving forces and stakeholder groups with an interest in regional transformation, i.e. the strengthening of the meso-level also played a considerable role in the field of development policy. In the decades of the "Europe of Regions", the EU served as an exogeneous driver of regional decentralisation for a while. The invasive effect of Structural Funds (SF) on national administrations was grounded in the need to procure development resources for less developed regions, especially in Eastern European member states. Europeanisation and conditionalism were imposed directly by the management regime of the Structural Funds (Hughes et al., 2004). The European principles of subsidiarity and partnership enforced in cohesion policy promoted the inclusion of regions in decision-making processes, which, in turn, have become the most virulent factors of multilevel governance (Bache, 1998).

It is not surprising that the newly constructed regions could not become influential political stakeholders in a number of countries in the EU (Ó. Cerbhaill, 1992; Loewen, 2018). The frequently shallow implementation of "radical" regional reforms especially in CEE countries did not trigger substantive changes beyond the administrative and political institutional structure (Lazareviciute and Verheijen, 2000). The survival of the legacies of the past, cultures and old power mechanisms point to the failure of regionalisation to lead to effective political decentralisation (Scott, 2009). A declining commitment characterized the new member states to adopting EU standards after the enlargement in 2004, and the EU's weakening position has also favoured central governments. This decline indicates that meso-level governance reforms in Eastern Europe were shaped by a very complex set of factors beyond external pressure from the EU (Saarts, 2019).

Rising Euroscepticism, conflicts with various "illiberal" democracies and lately the regime of pandemic management have brought into question the importance of the EU and its political values such as regionalism. The influence of national governments less supportive of regional decentralisation is steadily increasing. It is important to note that regionalisation even in its heyday was not always coterminous with the strengthening of the meso level and democracy, by imposing an extra political platform. Regional development partnership as an EU-imposed requirement led to the emergence of exclusive elite clubs, regional participation could not become virulent in the absence of regional identity (Piattoni and Polverari, 2016).

The power position of the meso level is not only determined by the national and supranational levels but by municipalities at the bottom as well. Vertical linkages between the bottom and the meso are influenced by several factors and are incarnated in different models. Analysing this complex system of relations with the methodological toolkit of political science would be highly useful. Following Bobbio (2002) cited by Škarica (2020) classification we can identify dependency, separation, cooperation and competition models based on regulation, competences, resources, political aspects, etc. In Croatia, for instance, the relations forged by municipalities and counties are characterized by conflict and competition due to past legacies that have preserved the strong position and paternalistic ambition of counties (Škarica, 2020). Theoretically, of course, there are win-win situations as well, where/ when the municipal and meso levels are cooperating. As outlined in the next sections, the Hungarian case presents a completely different picture illustrating the fate of declining counties that are unable to cooperate with the municipalities and assist them in the efficient operation of the self-government sector. The counties' inability to counterbalance the dominance of central government is explained by the lack of a strong alliance with the municipalities.

In overall, beyond the determining influence of their relations with higher (national/EU) and lower governance levels, the power position of meso-level governments is also shaped by their capacity to develop horizontal co-operations with nongovernmental stakeholders and their level of embeddedness in the social fabric on the basis of regional identity. The Hungarian case will demonstrate the fragile position of the meso in these power dimensions. Neither external nor domestic institutional and social frameworks have supported the involvement of the meso in the political arena.

\section{THE HISTORY OF HUNGARIAN COUNTIES}

\section{Legacy of Centralisation}

Centralization has been a permanent feature of the Hungarian state throughout its 1000 -years history and counties have been the traditional units of the government system. Counties protected the king and later the nobility. This feudal structure was upheld until the Civil Revolution in 1848-1849. Relatively strong powers were transferred to meso level self-governments by the 1870 Act on Municipal Authorities, which regulated the public administration in a comprehensive way. In 1950, Hungary's integration into the Soviet Empire entailed the introduction of the Leninist local council system. The model was essentially hierarchical and centralized within the framework of a socialist unitary state. Local and county elected councils were not the organs of local power but the local organs of (unitary) power (Beér, 1951). The county level continued to function as the servile transmitting unit of central government. 


\section{Systemic Change and Two Decades of Hesitation}

The systemic change in 1990 brought an unprecedented opportunity to establish a democratic political and decentralised governance system. The Act on Local Governments fundamentally transformed the spatial distribution of power, designating municipalities as the basic level units of the local government system. The virtual elimination of county power was justified by the need to focus policy attention at the bottom level and the small size of counties relative to European regions. Shortages of competences, means and resources of county governments were compounded with their unstable political legitimacy rooted in the indirect election system and diminished public trust surrounding county assemblies reflecting their unpopular role before the systemic change. To exploit this power vacuum, the central government and more specifically, the ministries established their own "bridge-head" positions at the meso-level by creating dozens of deconcentrated administrative offices subsumed under ministerial control. The tasks delegated to county governments related mostly to the maintenance of public service institutions overshadowed their effective spatial coordinating role, and the operation of hospitals, secondary schools, nursery and children's homes, museums, libraries, etc. highlighted their "caretaker" functions at the expense of governance.

The subsequent decade was marked by relentless reform attempts at the rescaling of territorial administration under external pressure from the EU. As a candidate for EU membership, Hungary had made substantial efforts to adjust its governance system to EU requirements. There was no agreement as to whether micro-regions, counties or the newly designated regional (NUTS2) level should become the main action spaces of development policy. Pursuant to the Act on Territorial Development and Spatial Planning of 1996, socalled development councils were established at various (national, regional, county and micro-regional) scales in parallel to the traditional system of public administration. In this plethora of new bodies the newly designated 7 macro (NUTS2) regions could not become central actors of regional policy, further eroding the position of the 19 county selfgovernments. The new leftwing/liberal government announced a radical programme of regionalisation in 2002, namely the election of the 7 regional governments for the first time in the history of Hungary. Despite the failure of the ambitious governmental programme, the government reelected in 2006 renewed its attempts to undertake a comprehensive reform. While the lack of two-third parliamentary support was believed to be the cause of the failed reform, regionalisation was not included in the central governmental agenda. However, the 7 regional development councils and agencies became the most influential units thanks to their skilled staff and experience in partnership cooperation. In the wake of EU accession in 2004, the entire institutional system of national development policy lost its positions, including the regional level. Strong centralisation has been an enduring feature of the management of EU Structural Funds. As illustrated by the Hungarian experience, territorial governance reforms cannot and should not be perceived solely as a part of the European adaptation process and subordinated to the absorption of EU funds. It was already evident in that period that the friendship of the governmental political elite was much more feigned than a rational and valuebased attitude.

\section{Hangover After 2010: The Past Has Returned}

In 2010 the rightwing government gained dominant power position thanks to winning two-third Parliamentary majority. As a result of drastic constitutional and functional reforms in the spirit of the "neo-Weberian" and illiberal state, centralisation and nationalisation have become the defining features of the Hungarian state and politics weakening all types of autonomies. The original text of the new Constitution (revised for the ninth time since 2011) was imbued by a radically new political philosophy defying the previous liberal political values aligned to European standards. The strong, all-dominating state power, the reversal of the system of checks and balances foreshadowed the curtailment of the role and independence of local and county governments as public autonomies. The post2011 changes have amply demonstrated the validity of the assumptions of that era.

A new act on local governments was adopted in 2011. The position of self-governments underwent serious modifications affecting their role, status and relations with the central government. The role of elected local/territorial selfgovernments was significantly reduced in favour of the territorial state (deconcentrated) administration. Counties as geographical units were subordinated to increasing central, top-down state influence, undermining their operation as elected, bottom-up units of self-governance. This transition has completely modified power relations among the various tiers of governance.

The new political regime has terminated the debate on the role of the meso scale, preserving counties as geographical units with the status of elected self-governments yet severely curtailing their previous powers. The operation of numerous public service institutions (hospitals, schools, elderly and children's homes, museums, libraries, etc.) was taken over by the state. What counties received as "compensation" was a very vaguely defined regional development mission.

County government offices headed by a government commissioner appointed by the prime minister have emerged as more powerful organisations than elected autonomous county assemblies. The deconcentrated administrative sector charged with the management of hospitals, schools, elderly homes, etc. has been greatly expanded at the expense of the elected county assemblies. The proliferating tasks of state and county government offices prompted the creation of new territorial administrative units, i.e. districts (175 in the counties and 23 in the capital) bringing the country-wide mega-organizations closer to citizens. 
In the meantime, the special status of county towns (county seats and cities with over 50,000 inhabitants, i.e. a total of 23 cities) has been upheld. For this reason, the jurisdiction of county self-governments still does not extend to these cities, which contributes to the lack of territorial cooperation between the city centres and the surrounding county governments.

In overall, county governments emerged as the main losers of the changing model of local governance once more, being practically excluded from the delivery of public tasks. The only "winners" of the process were big cities, also deprived of a considerable share of their public service functions (with public education constituting the most sensitive issue), however, local governments remained in charge of the operation of settlements, which promoted the privileged development of big cities later on. This confirms the special salience of electoral outcomes in big cities, calling into question the success of the paternalistic politics of the Government.

\section{POLITICS BETWEEN THE TOP AND THE BOTTOM FOCUSING ON THE ELECTIONS}

This section provides an overview of the results of county elections as a common theme of politics. The presented case study demonstrates the partial validity of the original theory of second-order elections in case of the extreme weakness of mesolevel governance, although scholars have drawn attention to the particular salience of regional elections in various countries over the last decades (Schakel and Jeffery, 2012). The Hungarian case is instructive in several respects. Despite the almost complete elimination of counties from the political arena, larger cities (and the capital) where the opposition won the elections have been transformed into buffer zones provoking strong political clashes. The political weightlessness of counties did not encourage voters to express their definite opinions, and the presence and activity of parties and civil organisations at county level was significantly reduced.

\section{Less Territoriality in Parliamentary Elections}

The post-2010 reform of the electoral system perfectly mirrors the political ambitions of the legislator, i.e. the concentration of power in one hand while minimising effective competition. The law introduced a one-round model of parliamentary elections containing compensational mechanism but showing more commonalities with majoritarian systems with a higher proportion of individual mandates obtained in individual districts. The number of MPs was cut in half (199), comprising 106 individual seats (53.3\%) and 93 county-wide party-list seats. The new delineation of individual electoral districts reveals a logic of gerrymandering to counter the leftist dominance of cities by integrating tiny peri-urban settlements experienced in the formal elections.

The abolition of county-wide party election lists has had drastic consequences, leading to the de facto demise of countylevel party politics. This change indicates that the ruling political elite had no intention to support the meso-level political game despite growing awareness of the importance of parties in the integration of governance levels, and the profound impact of their inner structure on the policy efficiency of the government (Saglie, 2019). Hungarian parties no longer needed county-level representation, having no demand for county programs, campaigns, nominating well-known, authentic personalities, etc. The abolition of party lists has almost completely dissolved the county party elite and administration, and the county-level political platform has been replaced by parliamentary single-member districts becoming the new working channels between top and bottom tiers of government.

The abolition of the dual mandate of MPs and mayors has further widened the gap between the local/county and the national political elite. The number of MPs with dual mandates (68 in 1994 and 166 in 2010 out of the 386 MPs) illustrates the vital and personal relations between central and local/county tiers before 2010 (Pálné Kovács et al., 2016). Apparently, the model has not proven to be successful, the mayors could have done more lobbying for their respective counties or settlements (Várnagy, 2012) instead of making the parliament more "territorially sensitive". On the whole, the legislator has not become the "friend of local governments", the drastic dethronement of the entire local government system was paradoxically approved by the last Parliamentary assembly attended by a high number of mayor-MPs in 2011 in their last period of dual mandate.

\section{Unfavourable Changes in Local/County Election System}

In 1990, county assemblies were created through an "indirect electoral" delegation method ensuring the dominance of independent mayors of smaller settlements whilst undermining the role of political parties. The model was well-suited to the will of the legislator to minimize the power of counties. The political elite bypassed this platform of politics handing over the arena for "minor issues" of no political salience.

Post-1994, direct county elections were conducted on a listbasis, reflecting the legislator's new ambition to strengthen the role of counties as meso-level political actors (in a highly contradictory manner). The lists were set up in two artificial electoral districts, differentiating between municipalities with fewer and more than 10,000 residents, but cities with county rank were still unable to elect representatives. This election model did not connect county assembly representatives to their own regions.

The new law in 2010 on the election of local and county council members and mayors has substantially transformed the previous system from several aspects. In line with the general political strategy to reduce the size of representative bodies, the number of local representatives in the case of counties and larger cities was reduced by more than half. The former dual-list system has been eliminated. The single lists of parties have resulted in improved transparency, which implies no strict loss of territoriality, however, as a more symbolic amendment, other civil organizations outside the parties may only set up their lists if 
TABLE 1 | Number of members in the county general assemblies and their breakdown by nominating organisations, 2014.

\begin{tabular}{|c|c|c|c|c|c|c|c|}
\hline \multirow[t]{2}{*}{ County } & \multirow{2}{*}{$\begin{array}{l}\text { Number of } \\
\text { members in } \\
\text { the general } \\
\text { assembly }\end{array}$} & \multicolumn{6}{|c|}{ Parties, Nominating organisations } \\
\hline & & FIDESZ-KDNP & Jobbik & MSZP & DK & LMP & $\begin{array}{c}\text { Other non- } \\
\text { party org }\end{array}$ \\
\hline Pest & 43 & 23 & 8 & 5 & 4 & 3 & - \\
\hline Fejér & 20 & 13 & 4 & 2 & 1 & - & - \\
\hline Komárom-E & 15 & 9 & 3 & 2 & 1 & - & - \\
\hline Veszprém & 17 & 10 & 3 & 3 & 1 & - & - \\
\hline Győr-M.-S & 21 & 14 & 4 & 2 & 1 & - & - \\
\hline Vas & 15 & 10 & 2 & 2 & - & - & 1 \\
\hline Zala & 15 & 9 & 4 & 1 & 1 & - & - \\
\hline Baranya & 19 & 11 & 3 & 3 & - & 1 & 1 \\
\hline Somogy & 16 & 9 & 3 & 1 & 1 & - & 2 \\
\hline Tolna & 15 & 8 & 3 & 2 & 1 & - & 1 \\
\hline Borsod-A.-Z & 29 & 15 & 8 & 5 & 1 & - & - \\
\hline Heves & 15 & 8 & 4 & 2 & 1 & - & - \\
\hline Nógrád & 15 & 9 & 3 & 2 & 1 & - & - \\
\hline Hajdú-B & 24 & 14 & 6 & 3 & 1 & - & - \\
\hline Jász-N.-Sz & 19 & 11 & 5 & 2 & 1 & - & - \\
\hline Szabolcs-Sz.-B & 25 & 16 & 5 & 3 & - & - & 1 \\
\hline Bács-K & 24 & 14 & 5 & 3 & 1 & 1 & - \\
\hline Békés & 18 & 11 & 4 & 2 & 1 & - & - \\
\hline Csongrád & 20 & 11 & 4 & 5 & - & - & - \\
\hline
\end{tabular}

Source: www.valasztas.hu

they obtain support from a min. of $1 \%$ of the county population instead of the previous $0.3 \%$.

The separate timing of parliamentary and local elections and the ensuing extension of the period of local/county elections from four to five years has downplayed the role of local and county politics. According to the literature, timing has proven to be a crucial factor in electoral turnout, defying traditional views on second-order elections. Hence, in addition to "less being at stake", the concrete political situation could also weigh significantly in parliamentary and local elections (Massetti, 2018; Gendzwill, 2019). Despite the separate timing of national and local elections in Hungary, the new figures of turnout underline the explanatory role of the scope of power instead of concentrated attention to the local elections. Likewise, low electoral turnout in Czechia is also explained by a lack of stake and low interest of voters (Pink and Eibl, 2018), despite a 3-years-long interval separating parliamentary and regional elections. Paradoxically, the stake of local elections became more important than ever in Hungary when the opposition could mobilise voters against the parties in power in 2019 one year after the parliamentary election.

\section{Election Results}

The results of county elections in 2014 demonstrated or reproduced the dominance of the ruling parliamentary conservative party coalition (FIDESZ-KDNP), As a result of the geographic polarisation of the electorate of the two stronger parliamentary oppositional parties (the rightwing "Jobbik" and leftwing MSZP), counties have remained the firm background for the nation-wide politics of the ruling party (Kákai and Pálné Kovács, 2021, Table 1). It has only been possible to vote for 72 (mostly party) lists, contrary to the previous approximately 500 nominating organisations in 2010 under the former electoral regulations (Dobos, 2011:72). The results of the 2014 elections clearly demonstrate the dominance of parties, and the perceived strong majority of governing parties (with joint lists) in each of the counties.

Non-party organisations were almost completely eliminated from the county assemblies (as a result of the 2014 elections, only 3 among the 418 representatives elected in the counties are independent members). It is interesting to compare this phenomenon with the case of Slovakia, where a dramatic increase in the share of independent deputies was witnessed in 2017 due to specificities of the electoral system providing a chance for independent candidates to run also (Rybar, 2019). The results of Czech regional elections were similar to those observed in Hungary. Although the majority of national parties did not conduct a separate campaign with special manifestos, only "regional parties" (in the legal form of civil alliances) drafted real regional programmes, which proved to be insufficient. National parties won the elections in the regional assemblies (Pink and Eibl, 2018).

Among the 104 county lists, 89 managed to cross the 5-percent threshold of entry in the given counties in 2019. FIDESZ-KDNP emerged as the uncontested winner of county assembly elections, with their lists winning the absolute majority of seats in each county (Table 2 ). The ruling party coalition gained 258 out of the 414 seats (62\%), further improving its results achieved five years earlier, when it won 245 seats (59\%). The analysis of the proportion of winning mandates of the party alliance (varying between 73.3 and 54\%) does not reveal any marked territorial pattern or rationale underlying the victory (Zongor, 2020).

The General Assembly of Budapest is the only exception where the FIDESZ-KDNP party alliance gained a "mere" 39 percent of mandates. A comparison of our results with data on cities with 
TABLE 2 | The proportion of mandates held by FIDESZ-KDNP in county assemblies in 2014 and 2019

\begin{tabular}{lcc} 
County & $\begin{array}{c}\text { 2014 county assembly } \\
\text { elections }\end{array}$ & $\begin{array}{c}\text { 2019 county assembly } \\
\text { elections }\end{array}$ \\
\hline Bács-Kiskun & 58.3 & 69.6 \\
Baranya & 57.8 & 66.7 \\
Békés & 61.1 & 58.8 \\
Borsod-Abaúj-Zemplén & 51.7 & 62.0 \\
Csongrád & 55.0 & 60.0 \\
Fejér & 65.0 & 70.0 \\
Győr-Moson-Sopron & 66.7 & 71.4 \\
Hajdú-Bihar & 58.3 & 66.7 \\
Heves & 53.3 & 66.0 \\
Jász-Nagykun-Szolnok & 57.9 & 61.1 \\
Komárom-Esztergom & 60.0 & 60.0 \\
Nógrád & 60.0 & 66.7 \\
Pest & 53,4 & 54.5 \\
Capital & 60.6 & 39.3 \\
Somogy & 56.2 & 60.0 \\
Szabolcs-Szatmár-Bereg & 64.0 & 72.0 \\
Tolna & 53.3 & 66.7 \\
Vas & 66.7 & 73.3 \\
Veszprém & 58.8 & 58.8 \\
Zala & 60.0 & 73.3 \\
Average & $\mathbf{5 8 . 9}$ & $\mathbf{6 3 . 5}$ \\
& & \\
\hline
\end{tabular}

Source: $h$ ttps://www.valasztas.hu/valasztasok-szavazasok

county rank indicates a greater volatility in the latter settlement category, as illustrated by the declining share of mandates held by FIDESZ-KDNP, dropping from 65 percent to 48 percent by 2019 . A comparison of data indicates no direct correlation in the case of cities with county rank and county assemblies, since the FIDESZKDNP party alliance managed to win nearly two-thirds of mandates in general assemblies of the counties. The most significant decline was observed in larger cities with county rank, ten of which were taken over by the Opposition (Table 3).

In overall, counties no longer operate as platforms of political competition due to their declining importance and the reluctance of parties to compete (the role of the people and publicity will be introduced later on). Larger cities appear to be more vital territorial platforms of politics, and for the opposition, while non-party and independent civil organizations have been de facto eliminated from local/territorial politics (Tables 4 and 5).

\section{GOVERNING WITHOUT POWER? SOME EMPIRICAL EVIDENCE ABOUT THE FUNCTIONING OF COUNTY ASSEMBLIES}

The section below deals with the activity of county selfgovernments after 2011. The issue of weak authorisation combined with formally strong public status relying on electoral legitimacy in the current knock-out position is worth exploring. An empirical research launched in 2016 was seeking to determine, on the basis of representative factors underlying the operation of county self-governments whether this tier of government (theoretically) endowed with political legitimacy has any effective scope of action. The research relied mostly on qualitative methods: we analysed documents on the
TABLE 3 | The proportion of mandates held by FIDESZ-KDNP in county towns in 2014 and 2019

\begin{tabular}{|c|c|c|}
\hline County & $\begin{array}{l}2014 \text { elections in } \\
\text { county towns }\end{array}$ & $\begin{array}{l}2019 \text { elections in } \\
\text { county towns }\end{array}$ \\
\hline Pécs & 71.4 & 26.9 \\
\hline Kecskemét & 72.7 & 57.1 \\
\hline Békéscsaba & 61.1 & 38.9 \\
\hline Miskolc & 62.0 & 35.7 \\
\hline Hódmezővásárhely & 73.3 & 33.3 \\
\hline Szeged & 31.0 & 31.0 \\
\hline Dunaújváros & 66.7 & 26.7 \\
\hline Székesfehérvár & 66.7 & 61.9 \\
\hline Győr & 66.7 & 69.6 \\
\hline Sopron & 66.7 & 72.2 \\
\hline Debrecen & 71.4 & 72.7 \\
\hline Eger & 66.7 & 33.3 \\
\hline Szolnok & 72.2 & 44.4 \\
\hline Tatabánya & 66.7 & 44.4 \\
\hline Salgótarján & 33.3 & 33.3 \\
\hline Érd & 72.2 & 33.3 \\
\hline Kaposvár & 72.2 & 72.2 \\
\hline Nyíregyháza & 68.2 & 59.0 \\
\hline Szekszárd & 66.7 & 46.7 \\
\hline Szombathely & 47.6 & 38.0 \\
\hline Veszprém & 72.2 & 61.1 \\
\hline Nagykanizsa & 73.3 & 46.7 \\
\hline Zalaegerszeg & 72.2 & 72.2 \\
\hline Average & 64.9 & 48.2 \\
\hline
\end{tabular}

Source: https://www.valasztas.hu/valasztasok-szavazasok

organisational structure, internal legal regulations and decisions taken by individual county assemblies, and conducted interviews among elected county leaders and officers (the results of the research were published in a monograph (Pálné Kovács, 2019).

The research was based on the assumption that despite their shrinking compulsory tasks and financial resources, the narrow public legal authorisation of counties encouraged them to take on voluntary missions and to fill existing functional gaps in the governance system. The political challenge was whether the meso-level would manage to survive and find a stable place within the public political arena.

\section{Who are the County Politicians?}

As already pointed out in the previous section, the ruling parties (FIDESZ- KDNP) achieved victory in all of the counties in 2019 (as in 2014). The winning of the majority of votes eliminated all political obstacles to maintaining a "peaceful", cooperative relationship with the central government, but the uniform party context at central and county level acted against reinforcing the political influence of the meso. In this respect, county elections had no rewarding or punitive function vis-à-vis the ruling parties, in contrast to the victory of the opposition in the big provincial cities.

Investigating the membership of county assemblies, we have found that the majority of presidents and county representatives are newcomers in the county self-governments. With the elimination of the dual mandate (local and national), a large number of formerly embedded county politicians opted for a mandate in the Parliament during the parliamentary elections of 2018 (Pálné Kovács, 2019). As demonstrated by the theory of 
TABLE 4 | A comparison of results of open-list elections of county assemblies, 2014-2019.

\begin{tabular}{|c|c|c|c|c|c|c|}
\hline & \multicolumn{3}{|c|}{2014} & \multicolumn{3}{|c|}{2019} \\
\hline & Ruling parties & Opposition parties & Civil organizations & Ruling parties & Opposition parties & Civil organizations \\
\hline Number of nominating organizations & 2 & 9 & 8 & 2 & 8 & 4 \\
\hline Number of candidates included on lists & 674 & 1,317 & 93 & 619 & 1,157 & 32 \\
\hline Number of obtained mandates & 225 & 156 & 4 & 245 & 132 & 4 \\
\hline Share of votes received (\%) & 52.6 & 45.5 & 1.8 & 57.2 & 41.2 & 1.6 \\
\hline
\end{tabular}

Source: $h t t p s: / / w w w . v a l a s z t a s . h u / v a l a s z t a s o k-s z a v a z a s o k$

TABLE 5 | A comparison of electoral data on larger city government representatives, 2014-2019.

\begin{tabular}{|c|c|c|c|c|c|c|c|c|c|}
\hline & & \multicolumn{4}{|c|}{2014} & \multicolumn{4}{|c|}{2019} \\
\hline & & $\begin{array}{l}\text { Ruling } \\
\text { parties }\end{array}$ & $\begin{array}{l}\text { Opposition } \\
\text { parties }\end{array}$ & $\begin{array}{c}\text { Civil } \\
\text { organizations }\end{array}$ & $\begin{array}{l}\text { Independent } \\
\text { candidates }\end{array}$ & $\begin{array}{c}\text { Ruling } \\
\text { parties }\end{array}$ & $\begin{array}{l}\text { Opposition } \\
\text { parties }\end{array}$ & $\begin{array}{c}\text { Civil } \\
\text { organizations }\end{array}$ & $\begin{array}{c}\text { Independent } \\
\text { candidates }\end{array}$ \\
\hline \multirow{2}{*}{$\begin{array}{l}\text { Number of nominating } \\
\text { organizations }\end{array}$} & County towns & 2 & 17 & 28 & - & 2 & 10 & 41 & - \\
\hline & $\begin{array}{l}\text { Capital city } \\
\text { districts }\end{array}$ & 2 & 15 & 15 & - & 2 & 12 & 25 & - \\
\hline \multirow[t]{2}{*}{ Number of Candidates } & County towns & 315 & 1,142 & 192 & 90 & 311 & 487 & 298 & 50 \\
\hline & $\begin{array}{l}\text { Capital city } \\
\text { districts }\end{array}$ & 293 & 1,197 & 93 & 42 & 289 & 503 & 168 & 56 \\
\hline \multirow{2}{*}{$\begin{array}{l}\text { Number of obtained } \\
\text { mandates }\end{array}$} & County towns & 282 & 150 & 8 & 5 & 214 & 147 & 74 & 3 \\
\hline & $\begin{array}{l}\text { Capital city } \\
\text { districts }\end{array}$ & 237 & 168 & 8 & 1 & 149 & 246 & 11 & 2 \\
\hline \multirow[t]{2}{*}{ Share of votes received (\%) } & County towns & 45.7 & 48.4 & 3.0 & 2.9 & 45.8 & 37.1 & 15.1 & 2.1 \\
\hline & $\begin{array}{l}\text { Capital city } \\
\text { districts }\end{array}$ & 43.4 & 53.6 & 2.3 & 0.7 & 41.2 & 53.8 & 3.9 & 1.1 \\
\hline
\end{tabular}

Source: https://www.valasztas.hu/valasztasok-szavazasok

second order elections, the restriction of the power position can contribute to the contra selection of actors. The role of "second order" politicians in the county assemblies did not become pervasive, i.e. those elected due to voters' lack of stakes regarding their choice of party lists. This leaves a larger room for "habitual" party preferences.

Another approach of our research was to identify which organisations were invited to take part at the plenary meetings of the respective counties besides the elected members of county assemblies since this information is accessible in the internal laws. According to our assumption, the horizontal system of relations can compensate, to a certain extent, the absence of de facto public service delivery, planning and development functions, allowing for a greater autonomy in relationship building. The lists of officially listed "partners" indicate the weak institutional embeddedness of county self-governments. The partnership of county self-governments has considerably deteriorated in both numerical and qualitative terms. As an alternative to strong civil partnership, we have detected substantial efforts to construct personal relationships with the central government. This attitude revealed by our interviews was naturally characteristic to previous periods as well. Nonetheless, there were a number of counties and county politicians that saw a perspective in the building of horizontal relations. This ambition has completely vanished, counties have become increasingly inward-looking.

The quality of operation is also conditioned by the existing administrative capacities. We found that not only strong politicians, but the supportive administrative staff was also lacking. As anticipated, there has been a drastic reduction of the size of official apparatuses, attaining only a small fraction of the former offices counting 100-150 members. This is a cause and consequence at the same time, weak administrative capacities reflect the sharp curtailment of responsibilities, pose insurmountable barriers to the pursuit of activities beyond those related to development policy. Moreover, the small group of experts in county council offices were unable to ensure the delivery even of the residual tasks, which limits their capacity to assist municipalities in planning, implementing and managing projects.

\section{Asymmetric Connections With Local and Central Levels}

The essence of county level government is to integrate and collaborate with local governmental stakeholders. We tried to obtain information on this issue despite difficulties encountered in the reconstruction of institutional and non-systemic relations. The system of relations of county self-governments with municipal self-governments are strikingly unbalanced in the Hungarian counties. Where counties consist of viable large settlements, towns and cities, municipal mayors have no need for "paternalistic parenting". The historical role of counties was the mediation of central interests, and inherited prejudices decrease their popularity among municipal leaders. Declining 
interest in cooperation with municipalities is also explained by a reduction of their functions, limited to servile assistance in centralised money allocation. As already mentioned, relationships with the county seat cities are more complicated, full of conflicts and rivalry not only because of the legal regulation but also the competition for development projects. Relations with cities ruled by the opposition are problematic or absent, more likely to be regarded as rivals than partners.

The relationship system between county self-governments and the central government and parties is less conflictual. This is partly explained by the governing parties' majority in the county bodies, but also the recognition of the importance of maintaining good relations with central government actors, given the prevailing clientelism in the allocation of resources (Pálmai, 2014; Balogh, 2015; Medve-Bálint, 2018). The centralised mechanism of development policy has generated a new spatial framework of lobbying, transforming the former territorial channels of power. The individual parliamentary electoral districts, that is the members of Parliament became the key figures of the politically determined resource allocation. Counties as self-governments are excluded from effective political decision-making. The presidents and members of county assemblies are not included in the narrower circle of power, their severely curtailed competencies and weak local embeddedness relegate them to the role of secondary rank politicians. A comparison with the situation in France is instructive, where the personal power of local, county and regional politicians is cumulated and the main driving forces of decentralisation are fuelled by the personal power ambitions of local politicians (Jérôme and Lewis-Beck, 1999; Rodden and Wibbels, 2010). Hungary, on the other hand, is characterised by a strong correlation between weak politicians and weak counties, county politicians are removed from the top of the power hierarchy and the link between the meso and the central level is "centralised" in a sense that the mediatory role of actors is embedded in their central position (such as parliamentary MPs) and does not depend on their local embeddedness.

According to interviews with county leaders, the National Association of Counties has also lost its political influence. They admitted that they were unable to conduct successful consultations on a higher government level as compared to the superior interest enforcement capacity of county seat cities and their national association. The devaluation of the importance of counties, that is, rural areas is visible in the cities' much higher share of resources from EU funds and the government-initiated Modern Cities programme. The latter clearly illustrates the dire consequences of the exclusion of counties. In the absence of the meso, Hungarian rural areas and small settlements are unable to persuade the government to ensure a more equitable allocation of resources.

\section{What About the People? No Social Embeddedness}

Civil, democratic embeddedness and identity are crucial factors in the legitimacy of regional governments. Power position is hard to preserve in the lack of democratic support. It was already frustrating during the dramatic reform processes around 2010-2011 that while the shift towards stronger central state authority was politically contested by the associations of selfgovernments and oppositional parties, the majority of the population remained strikingly neutral to massive centralisation.

When conflicts between governance levels bypass publicity, what remains is private bargaining with meagre chances of victory. County assemblies's efforts to "sell" their mission to the public had no success and were manifest in the generally lower voter turnout at the local and county elections (Table 6), underlining the relevance of the theory of second-order elections. Asymmetric media power relations based on the ruling party's monopolistic ownership, the unfairly higher incomes generated from public advertising may have strongly contributed to asymmetries in voter turnout and choice. In rural and smalltown regions, outside the Capital and the major cities, local election campaigns were almost exclusively shaped by the government-dominated public media. The social media played a more prominent role in urbanised regions with a higher percentage of young, educated people. In contrast, no explicit campaigning was conducted by county candidates. In the local and social media, there was hardly any trace of county campaigns. County assembly representatives are not really strong party cadres, and presidents of county assemblies are not directly elected, making it rather difficult to "sell" county politicians.

Furthermore, publicity is not a priority issue for the counties either. As also confirmed by our empirical findings (Pálné Kovács, 2019), county assemblies have not demonstrated much activity besides the continuous updating of their websites, which explains the feeble number of visitors of county webpages. Attendance of county-level public hearings is also rather low as has been reconstructed in the course of our research, and there is a quasi absence of public events for civilians.

It would be irreal to expect any serious improvement in the relationship between counties and their residents. A survey covering a representative sample of 1,500 respondents (Kákai, 2019) explored to what extent inhabitants were familiar with their respective counties and whether they had any preliminary knowledge about the functions of county self-governments. The findings were disappointing yet predictable. In total, 715 respondents had no knowledge about their counties, a further 58 refused to give an answer, which implies that half of the respondents did not have any idea about their county. The disappointing participation rates, the lack of county publicity follows from the lack of stake but also explains the passivity of the county elite.

\section{SUMMARY AND DISCUSSION}

It is safe to conclude that Hungarian counties are not real political actors capable of strengthening their territorial identity and preserving the functioning of a more democratic political system. In our attempt to detect the potential and effective partners of county self-governments, we have been practically 
TABLE 6 | Voter turnout rates during the last three elections, by county.

\begin{tabular}{|c|c|c|c|}
\hline County & 2018 parliamentary elections & 2019 EP elections & 2019 local/county elections \\
\hline Bács-Kiskun & 67.7 & 38.6 & 44.5 \\
\hline Baranya & 66.1 & 39.8 & 53.4 \\
\hline Békés & 68.0 & 37.6 & 47.1 \\
\hline Borsod-Abaúj-Zemplén & 66.8 & 36.9 & 53.6 \\
\hline Csongrád & 70.6 & 42.2 & 48.2 \\
\hline Fejér & 71.1 & 41.7 & 47.1 \\
\hline Győr-Moson-Sopron & 72.5 & 44.7 & 49.6 \\
\hline Hajdú-Bihar & 66.5 & 35.2 & 46.0 \\
\hline Heves & 70.9 & 40.1 & 52.2 \\
\hline Jász-Nagykun-Szolnok & 67.4 & 36.1 & 44.7 \\
\hline Komárom-Esztergom & 70.0 & 40.1 & 44.7 \\
\hline Nógrád & 67.6 & 38.2 & 53.6 \\
\hline Pest & 71.3 & 42.7 & 45.3 \\
\hline Somogy & 68.8 & 39.5 & 52.0 \\
\hline Szabolcs-Szatmár-Bereg & 68.2 & 36.8 & 54.8 \\
\hline Tolna & 67.4 & 38.9 & 49.8 \\
\hline Vas & 74.2 & 47.0 & 55.3 \\
\hline Veszprém & 72.1 & 43.9 & 49.2 \\
\hline Zala & 72.7 & 43.2 & 52.4 \\
\hline National average & 70.2 & 43.6 & 48.6 \\
\hline
\end{tabular}

Source: https://www.valasztas.hu/valasztasok-szavazasok

unable to identify any. At the local level, strong cities are not reliant on co-operation, relations are rather adverse with the leadership of cities ruled by the opposition. Smaller cities tend to develop ties with their adjoining villages, which poses significant hurdles to the political integration of counties as counterweights to central power. The central government is almost oblivious to the needs of counties, preferring to use county government offices as "arm's length institutions" in the management of centralised public tasks.

As elected self-governments, they have been almost completely wiped out from the territorial governance system, largely stripped of their assets, competences, local networks and legitimacy. County self-governments are the primary victims of strong centralisation in Hungary, triggering an absence of democratic meso-level institutions to counterbalance excessive central power. Endogenous driving forces of regional decentralisation are still lacking. County assemblies are situated in a power vacuum due to a lack of political will to strengthen their position, the government party's victory in county elections notwithstanding.

A review of the three-decade-long history of counties and our own researches suggest that although the theory of second order elections may assist us in the interpretation of processes, certain relations are more directly related to the overall social and political context of governance. The interest of the general public toward elections remains low and they are unaware of the significance of counties since the people have no cognitive or emotional connections with meso-level governance.

Local elections indicate the emergence of the control or counterweight function, in the case of bigger cities but not at the county level as a result of the territorial differences of party preferences but also the invisibility of counties for the average voter. The county self-governments do not even strive to reach the general public.
The analysis of wider relations of governance shows that the elimination of the county level from the political arena has upgraded the role of channels of central interest representation, as manifest in the strengthening lobbying of individual MPs. The electoral system is more likely the outcome than a cause of the devaluation of a mesogovernmental tier. It may however contribute to decreasing the number of platforms for the competition between parties. The parties themselves have undergone transformation, their cadres and organisational capacities are concentrated at the central tier, the implications of which should be explored by more in-depth research in the future.

The relationships of counties are also evolving, the counties have no real allies. The integration of the settlements, centres and peripheries of counties is becoming looser. An important conclusion to be drawn is that the stakeholders of decentralisation are lacking sufficient guarantees that would maintain their position and empowerment in the vertical governance relations. The fragile position of the "meso" is explained to a large extent by the jealousy of local governments, that is by the resistance of the political elite of municipalities, and especially the cities to their "subordination" to higher-level authorities.

Functional hollowing-out leads to a deterioration of social, horizontal, and civil relations as well. Electoral mobilisation encounters serious obstacles in countries where meso-tier government plays a marginal role in public service provision, development or other policies. Fostering electoral support in the case of invisible, weak representative bodies is a challenging task.

For this reason, county election outcomes did not pose significant political challenges, as illustrated by parties' practice of nominating "second-order" candidates and abstention from campaigning in the counties. The real challenge was posed by the Capital and those cities where the prospects of the Opposition 
were better. The victory of the Opposition in the Capital and ten larger cities in 2019 indicates a realistic possibility of their entering the macro political arena, while election outcomes in the rest of the municipalities carry a nationally significant political value and message, cementing the dominant singleparty position of the ruling FIDESZ-KDNP coalition. The events in the wake of the October 2019 local/county selfgovernment elections suggest that the Opposition has only won a battle but not the war. The declining position of local and county self-governments triggered by the COVID-19 pandemic is a further cause of concern. On the pretext of the crisis the central government has affected drastic cuts to the budget of local governments, the capital has been hit particularly hard and sharp debates have erupted between the "free" cities led by the Opposition and the central government amidst highly asymmetric power conditions.

However, further research evidence would be required to identify the appropriate model of territorial governance and decentralisation (Harbers, 2018) in conjunction with new directions of governance theories. Evidence suggests that where the local and territorial self-governments are politically weightless, it is easier to limit democratic public participation and

\section{REFERENCES}

Bache, I., Andreou, G., Atanasova, G., and Tomsic, D. (2011). Europeanization and Multi-Level Governance in South-East Europe: the Domestic Impact of EU Cohesion Policy and Pre-accession Aid. J. Eur. Public Pol. 18 (1), 122-141. doi:10.1080/13501763.2011.520884

Bache, I. (1998). The Politics of European Union Regional Policy: Multi-Level Governance or Flexible Gatekeeping? Sheffield: Sheffield Academic Press.

Bachtler, J., Martins, J. O., Wostner, P., and Zuber, P. (2017). Towards Cohesion Policy 4.0. Structural Transformation and Inclusive Growth. Brussels: Regional Studies Association.

Baldersheim, H., and Rose, L. (2010). Territorial Choice: The Politics of Boundaries and Borders. London: Palgrave-Macmillan.

Balogh, P. (2015). Development Trap? Belvedere Meridionale 27 (1), 86-101. doi:10.14232/belv.2015.1.7

Beér, J. (1951). Helyi Tanácsaink Államhatalmi Jellege (Public Character of the Local Soviets). Állam és Igazgatás 11-12, 593-606.

Bertrana, X., and Heinelt, H. (2013). The Second Tier of Local Government in the Context of European Multi-Level Government Systems: Institutional Setting and Prospects for Reform. Revista catalana de dret public 46, 73-89. doi:10.2436/20.8030.01.4

Bobbio, L. (2002). Governi Locali Nelle Democrazie Contemporanee [Local Authorities in Contemporary Democracies]. Rome, Italy: Laterza.

Brenner, N. (2004). New State Spaces. Urban Governance and the Rescaling of Statehood. Oxford: Oxford University Press.

Bucek, J., and Plesivcak, M. (2017). Self-government, Development and Political Extremism at the Regional Level: A Case Study from the Banska Bystrica Region in Slovakia. Sociológia 49 (6), 599-635.

Charron, N., Dijkstra, L., and Lapuente, V. (2013). Regional Governance Matters: Quality of Government within European Union Member States. Reg. Stud. 48, 68-90. doi:10.1080/00343404.2013.770141

Charron, N. (2016). "Quality of Government, Regional Autonomy and Cohesion Policy Allocations to EU Regions," in Handbook on Cohesion Policy in the EU. Editors S. Piattoni and L. Polverari (Cheltenham: Edward Elgar), 92-104.

Ch. Jeffery (Editor) (1997). The Regional Dimension of the European Union (London: Frank Cass).

Coleman, J. S. (1974). Power and Structure of Society. New York, WW: Norton Company. healthy competition. That said, within the system of multi-level governance, the modification of the scale, public service delivery role or power status of a given tier has implications for the entire system of actors. The position of the meso level, "floating" between central and local power ambitions, is highly fragile. The fate of Hungarian counties illustrates how politics without the meso level contributes to strengthening the positions of central political actors who are able to keep the power uncontrolled below.

\section{DATA AVAILABILITY STATEMENT}

The original contributions presented in the study are included in the article/Supplementary Material, further inquiries can be directed to the corresponding authors.

\section{AUTHOR CONTRIBUTIONS}

The author confirms being the sole contributor of this work and has approved it for publication.

Curtis, S. (2016). Cities and Global Governance: State Failure or a New Global Order?. Millennium J. Int. Stud. 44 (3), 455-477. doi:10.1177/ 0305829816637233

Dahl, R. A. (1961). Who Governs? New Haven: Yale University Press.

Dardanelli, P., Kincaid, J., Fenna, A., Kaiser, A., Lecours, A., Singh, A. K., et al. (2018). Dynamic De/Centralization in Federations: Comparative Conclusions. The J. Federalism 49, 194-219. doi:10.1093/publius/pjy037

Dobos, G. (2011). Elmozdulás Középszinten: A 2010-es Önkormányzati Választási Reform Hatásai a Megyei Önkormányzatokra [Shift at Meso-Level. The Impacts of Election Reform in 2010 on the County Self-Governments]. Politikatudományi Szemle 4, 61-83.

Faguet, J. P., Fox, A. M., and Pöschl, C. (2015). "Does Decentralisation Strengthen or Weaken the State? Authority and Social Learning in a Supple State," in Is Decentralisation Good for Development? Perspectives from Academics and Policy Makers. Editors J.-P. Faguet and C. Pöschl (Oxford: Oxford University Press).

F. Vallier, A. Poth-Mögele, and N. Noupadja (Editors) (2018). Europe 2030. Les territoires prennent la parole. Local leaders speak out (Paris: CEMR Editions Autrement).

Galaskiewicz, J., and Krohn, K. R. (1984). Positions, Roles, and Dependencies in a Community Interorganization System. Sociological Q. 25, 527-550. doi:10.1111/j.1533-8525.1984.tb00208.x

Gendzwill, A. (2019). Local Autonomy and National-Local Turnout gap: Higher Stakes, Higher Turnout? Reg. Fed. Stud. 31, 519-539. doi:10.1080/ 13597566.2019.1706496

Gendźwiłł, A., and Steyvers, K. (2021). Guest Editors' Introduction: Comparing Local Elections and Voting in Europe: Lower Rank, Different Kind. or Missing Link? or Missing Link? Local Government Stud. 47 (1), 1-10. doi:10.1080/ 03003930.2020 .1825387

G. Shabbir and D. Rondinelli (Editors) (2007). Decentralizing Governance. Emerging Concepts and Practices. Ash Institute for Democratic Governance and Innovation (Washington: Harvard University Brooking Institution Press).

Haasis, H. A. (1978). Kommunalpolitik und Machtstruktur. Frankfurt/Main: Haag-Herchen Verlag.

Halásková, M., and Halásková, R. (2015). The Structure and Financial Dimensions of Public Administration in EU Countries. Transylvanian Rev. Administrative Sci. $45,41-57$.

Harbers, I. (2018). "Contribution of the Postfunctionalist Theory of Governance to Subnational Research in Comparative Politics," in Territory, Politics, Governance. Measuring and Theorizing Regional Governance. Editors K. Eaton, J-P. Faguet, 
I. Harbers, A. H. Schakel, and L. Hoeghe (New York: Routledge). doi:10.1080/ 03003930.2017.1310102

Haus, M. (2014). Mirror of the State or Independent Image? - Conceptual Perspectives on the Question of a Legitimacy Shift to the Output Dimension in Local Democracy. Urban Res. Pract. 7, 123-136. doi:10.1080/ 17535069.2014.910919

H. Heinelt, Bertrana, X., and Egner, B (eds) (2016). Policy Making at Second Tier of Local Government in Europe. What Is Happening in Provinces, Counties, Départements, and Landkreise in the Ongoing Re-scaling of Statehood? Abingdon - New York, Routledge.

Hughes, J., Sasse, G., and Gordon, C. (2004). Conditionality and Compliance in the EU's Eastward Enlargement: Regional Policy and the Reform of Sub-national Government. Jcms: J. Common Market Stud. 42, 523-551. doi:10.1111/j.00219886.2004.00517.x

Jérôme, B., and Lewis-Beck, M. S. (1999). Is Local Politics Local? French Evidence. Eur. J. Polit. Res. 35, 181-197. doi:10.1111/1475-6765.00446

J. Loughlin, F. Hendriks, and A. Lidström (Editors) (2011). Oxford Handbook of Local and Regional Democracy in Europe (Oxford University Press).

Junjan, V. (2012). "Introduction to Public Administrative Reforms in CEE and CA Countries," in Public Sector Dynamics in Central and Eastern Europe. Editor Nemec de Vries (Bratislava: NISPAcee).

Kákai, L. (2019). Útkereső Önkormányzatok Magyarországon. Budapest: Nemzeti Közszolgálati Egyetem.

Kákai, L., and Pálné Kovács, I. (2021). Counties in a Vacuum: The Electoral Consequences of a Declining Meso-Tier in Hungary. Reg. Fed. Stud. 31 (3), 405-418. doi:10.1080/13597566.2020.1855148

Kaufmann, D., Kraay, A., and Mastruzzi, M. (2003). Governance Matters III: Governance Indicators for 1996-2002. Washington: World Bank. http://www. worldbank.org/wbi/governance/.

Keating, M. (2014). Introduction: Rescaling Interests. Territory, Polit. Governance 2, 239-248. doi:10.1080/21622671.2014.954604

K. Göymen and O. Sazak (Editors) (2014). (Istanbul: Istanbul Policy Center).Centralization Decentralisation Debate Revisited.

Kuhlmann, S., and Wollmann, H. (2014). Introduction to Comparative Public Administration: Administrative Systems and Reforms in Europe. Cheltenham: Edward Elgar.

Ladner, A., Keuffer, N., Baldersheim, H., Hlepas, N., Swianiewicz, P., Steyvers, K., et al. (2019). Patterns of Local Autonomy in Europe. Cham: Palgrave, Macmillan.

Lazareviciute, I., and Verheijen, T. (2000). "Efficient and Effective Government," in European Union Enlargement and the Open Society Agenda. Editors G. Péteri and O. Simek (Budapest: Local Government and Public AdministrationOSI/ LGI), 149-163.

Loewen, B. (2018). From Decentralization to Re-Centralization: Tendencies of Regional Policy and Inequalities in Central and Eastern Europe. Halduskultuur 18 (2), 103-126. doi:10.32994/ac.v18i2.162

Massetti, E. (2018). Regional Elections in Italy (2012-15): Low Turnout, Tri-polar Competition and Democratic Party's (Multi-level) Dominance. Reg. Fed. Stud. 28, 325-351. doi:10.1080/13597566.2018.1428568

Medve-Bálint, G. (2018). The Cohesion Policy on the EU's Eastern and Southern Periphery: Misallocated Funds? Stud. Comp. Int. Develop. 2, 208-238. doi:10.1007/s12116-018-9265-2

M. Keating (Editor) (2004). Regions and Regionalism in Europe (Northhampton: Edward Elgar).

Ó Cerbhaill, D. (1992). "Creatures of the centre? the Uneasy Relationship of central Government with Regional and Local Authorities," in Development Issues and Strategies in the New Europe. Editor M. Ireland Tykkylainen (Avebury: Aldershot), 211-220.

Pálmai, É. (2014). Evaluation of Using EU Funding Sources in the Regional OperativeProgrammes. DETUROPE 6 (3), 85-96.
Pálné Kovács, I. (2019). A Középszintü Kormányzatok Helyzete És Perspektivái Magyarországon. Budapest: Dialóg Campus.

Pálné Kovács, I., Zongor, G., Kacziba, P., Grünhut, Z., Finta, I., and Bodor, Á. (2016). Zbogom Decentralizaciji. HKJU-CCPA 16 (4), 789-816. doi:10.31297/hkju.16.4.4

Pink, M., and Eibl, O. (2018). The 2016 Czech Regional Elections: Without Real Regional Parties or Voters' Interest. Reg. Fed. Stud. 28 (3), 353-365. doi:10.1080/13597566.2018.1450746

Rodden, J., and Wibbels, E. (2010). Dual Accountability and the Nationalization of Party Competition: Evidence from Four Federations. Party Polit. 17 (5), 629-653. doi:10.1177/1354068810376182

Rodríguez-Pose, A., and Courty, J. (2018). Regional Lobbying and Structural Funds: Do Regional Representation Offices in Brussels Deliver? Reg. Fed. Stud. 28, 199-229. doi:10.1080/13597566.2018.1441828

Rodríguez-Pose, A., and Ezcurra, R. (2010). Does Decentralization Matter for Regional Disparities? A Cross-Country Analysis. J. Econ. Geogr. 10 (5), 619-644. doi:10.1093/jeg/lbp049

R. Scully and R. Wyn-Jones (Editors) (2010). Europe, Regions and European Regionalism (Houndmills: Palgrave Macmillan).

Rybar, M. (2019). The 2017 Regional Elections in Slovakia: Soaring Independents and Recovered Opposition in a Fragmented Political Space. Reg. Fed. Stud. 29, 441-458. doi:10.1080/13597566.2019.1568247

Saarts, T. (2019). Introducing Regional Self-Governments in Central and Eastern Europe: Paths to success and Failure. Reg. Fed. Stud. 30, 625-649. doi:10.1080/ 13597566.2019.1598383

Saglie, J. (2019). Do party Organizations Integrate Multi-Level States? case Norwegian Local Government Reform $=$ Reg. Fed. Stud. doi:10.1080/ 13597566.2019 .16842

Schakel, A. H., and Jeffery, C. (2012). Are Regional Elections Really 'second-Order' Elections?. Reg. Stud. 47 (3), 1-19. doi:10.1080/00343404.2012.690069

Schakel, A. H., and Romanova, V. (2018). Towards a Scholarship on Regional Elections. Reg. Fed. Stud. 28 (3), 233-252. doi:10.1080/ 13597566.2018.1473857

Schakel, A. H., and Romanova, V. (2020). Vertical Linkages between Regional and National Electoral Arenas and Their Impact on Multilevel Democracy. Reg. Fed. Stud. 30 (3), 323-342. doi:10.1080/13597566.2020.1774750

Škarica, M. (2020). Interplay between the Tiers in Croatian Local Government: Who Is Winning. HKJU-CCPA 20 (2), 207-240.

S. Piattoni and L. Polverari (Editors) (2016). Handbook on Cohesion Policy in the $E U$ (Cheltenham: Edward Elgar).

Várnagy, R. (2012). Polgármesterek a Magyar Országgyúlésben. Budapest: Corvinus Egyetem.

Zongor, G. (2020). A Kormánypártok Biztos Bázisai - Összefoglaló a Megyei Önkormányzati Választásokról. tavasz: Comitatus, 12-28.

Conflict of Interest: The author declares that the research was conducted in the absence of any commercial or financial relationships that could be construed as a potential conflict of interest.

Publisher's Note: All claims expressed in this article are solely those of the authors and do not necessarily represent those of their affiliated organizations, or those of the publisher, the editors and the reviewers. Any product that may be evaluated in this article, or claim that may be made by its manufacturer, is not guaranteed or endorsed by the publisher.

Copyright $(2021$ Pálné Kovács. This is an open-access article distributed under the terms of the Creative Commons Attribution License (CC BY). The use, distribution or reproduction in other forums is permitted, provided the original author(s) and the copyright owner(s) are credited and that the original publication in this journal is cited, in accordance with accepted academic practice. No use, distribution or reproduction is permitted which does not comply with these terms. 